\title{
PRESENTATION OF THE HENRY DUNANT MEDAL
}

As already announced, the Standing Commission of the International Red Cross, meeting in Mexico City last October, awarded the Henry Dunant Medal, the highest Red Cross distinction, to three outstanding persons: Mr. André François-Poncet, Mrs. Sachiko Hashimoto and Miss Katalin Durgo. The Standing Commission again met, this time in Geneva, on 11 April 1972, and that was when Mrs. Sachiko Hashimoto, Co-chairman of Japanese Junior Red Cross, received the medal from Angela, Countess of Limerick, Chairman of the Commission. As the other two medalists were unable to come to Geneva, they are to receive the award on some other occasion.

At the ceremony, the Chairman of the Standing Commission delivered an address in which she praised the medalist. A few passages are given below:

Since the beginning of her period of service with the Japanese Red Cross in 1948, Mrs. Hashimoto has concentrated on the promotion of world peace through international understanding, and on the dissemination of the Geneva Conventions. It is no exaggeration to say that in its work to disseminate knowledge of the Conventions among young people, the Japanese Red Cross has been among the world leaders. Its achievements in this field have been almost wholly due to the efforts of Mrs. Hashimoto.

Allied with this, she has worked unceasingly for the promotion of the type of international understanding which is the only lasting basis for a peaceful world. The number of imaginative projects by which the youth of Japan have learned more about the rest of the world, and the forms of international activities which they have pioneered, have been outstanding. Mrs. Hashimoto's leadership of the Japanese Youth Goodwill Cruise, which visited seven countries in South East Asia in early 1968, made a tremendous impression on the countries visited, 


\section{IN THE RED CROSS WORLD}

not to mention the lasting impression made on the participants themselves.

But probably the most significant of all Mrs. Hashimoto's achievements, and the one which has inspired us to nominate her for this award has been the Organization of "Konnichiewa '70"-a technical seminar for young representatives of National Red Cross Societies in the Pacific area, which took place in July, 1970. This seminar was the result of two years of preparation and the far-reaching plans made for follow-up are now in operation. The theme of the seminar"What are the responsibilities and obligations of Youth to the country and to the world community?" and "What can Youth do through the Red Cross?"-provided many opportunities for a genuine exchange of experiences between young people representing many different cultures but all subscribing to the basic principles and ideals of the Red Cross.

Mrs. Hashimoto in turn spoke. She said how much the high distinction she was being awarded meant to her. She referred to some of the phases of a life which she had largely devoted to Red Cross Youth, and concluded thus:

...I feel so humble and yet full of genuine joy and satisfaction as a Red Cross educator, as the recipient of the Henry Dunant Medal, initiated by the Australian Red Cross which I humbly accept as a good gesture of the big heart of the Standing Commission: now I am very happy and grateful to you all. All my people join me in my expressing the sentiment, including princesses, waiting for my return to see the first one in Japan impatiently. I am rather on their errand to carry it back a long, long way home. 